\title{
EFFECTS OF CLIMATE CHANGE ON POULTRY PRODUCTION IN ONDO STATE, NIGERIA
}

\author{
G.B. Adesiji, S.T. Baba, Researchers \\ Department of Agricultural extension and Rural Development, University of Ilorin, Nigeria
}

\author{
I.S. Tyabo, Researcher \\ Department of Agricultural Economic and Extension technology \\ Federal University of Technology, Minna, Nigeria \\ E-mail: drgbolaadesiji@yahoo.com
}

\begin{abstract}
The study assesses the effects of climate change on poultry production in Ondo State, Nigeria. Eighty three (83) poultry farmers were interviewed to elicit relevant information in line with the objectives of the study. Descriptive statistics and inferential statistical tools were used for data analysis. Findings revealed that majority (93.3\%) of the respondents are aware of climate change, $78 \%, 98.8 \%$ and $86.7 \%$ of the respondents agreed that temperature fluctuation, increased in sunshine intensity and global warming has a negative effects on poultry production, $72.4 \%$ of the respondents agreed that prices of feed grains are usually high in hot and dry seasons which may affect cost of production and number of birds to raise for egg and meat production in the farm, $73.5 \%$ of the respondents agreed that climate change has effect on feed grain availability, this implies that high temperature and low rainfall are climatic factors that affect general grain harvest, their supply to the market and ultimately cost of poultry production. the findings further revealed that $94 \%$ of the respondents agreed that climate change affects egg and meat production pattern and $95.2 \%$ of the respondents agreed that moist climatic conditions encouraged the distribution and development of diseases. Infrential statistics shows that there is a significant relationship between respondents' socio-economic characteristics and perception of poultry farmers on effects of climate change on poultry production since $p>0.05(r=0.454, p=0.001)$, the findings also shows that there is a significant relationship between socio-economic characteristics of respondents and their level of awareness of climate change since the $p>0.05(r=0.652, p=$ 0.001 ). it is recomended extension agents and other development agencies need to educate the poultry farmers more about the effects posed by climate change on poultry production and intensify awareness campaign to poultry farmers on how to reduce the effects of climate change on poultry production.
\end{abstract}

\section{KEY WORDS}

Poultry; Climatic change; Eggs; Meat; Egg shell; Production; Productivity; Products; Climate; Heat.

Poultry plays an important economic, nutritional and socio-cultural role in the livelihood of poor rural households in many developing countries, including Nigeria. Poultry are birds that include fowl, turkey, duck, goose, ostrich, guinea fowl, etc which render not only economic services but contribute significantly to human food as a primary supplier of meat, egg, raw materials to industries (feathers, waste products), source of income and employment to people compared to other domestic animals (Avila,1985; Demeke, 2004). Poultry are efficient converters of feed to egg and meat within a short period of time. In terms of nutritive value, poultry egg rank second to cow milk. Agriculturists and nutritionists have generally agreed that developing the poultry industry of Nigeria is the fastest means of bridging the protein deficiency gap presently prevailing in the country (Amos, 2006).

When ambient temperature is high, chickens have higher energy (feed) needs than when in thermoneutral environments. Major losses result from a less efficient conversion of feed to meat, which detrimentally impacts poultry health and productivity (Olanrewaju et al., 2010). Poultry flocks are particularly vulnerable to climate change because there is a range of thermal conditions within which animals are able to maintain a relatively stable body 
temperature in their behavioural and physiological activities. Hence, birds can only tolerate narrow temperature ranges to sustain the peak of their production for human consumption and any unpredictable climatic changes will therefore trigger a series of adjustment and readjustments by livestock and poultry birds in the struggle for survival which may have negative consequence on the viability of poultry production. The environmental conditions affecting the performance and health productivity of chicken include temperature, relative humidity, light, sunshine prevailing at a given time, housing system and ventilation (Elijah and Adedapo, 2006). Ambient temperatures significantly influence the survivability and performance of the poultry production. According to Indian Council for Agricultural Research (ICAR) (2010), as the ambient temperature increased to $\geq 34^{\circ} \mathrm{C}$ the mortality due to heat was significantly high in meat type chickens by $8.4 \%$, the feed consumption of the chickens decreases from $108.3 \mathrm{~g} / \mathrm{bird} /$ day at $31.6^{\circ} \mathrm{C}$ to $68.9 \mathrm{~g} / \mathrm{bird} /$ day at $37.9^{\circ} \mathrm{C}$, the egg production also decreased by $6.4 \%$ as compared to their standard egg production.

Climate change alters global disease distribution, affects poultry feed intake, encourage outbreak of diseases which invariably affects poultry output (egg and meat) and also cost of production (Guis et al (2011). Elijah and Adedapo (2006) reported in his study that high rainfall and relative humidity provides a conducive environment for breeding of parasites that causes out break of diseases which invariably reduces egg production. They further reported that temperature reduces the feed intake of poultry birds because more energy is needed to conserve the heat caused by high temperature, hence, a decreased in the rate of feed intake. Before now, Ondo Sate has good climatic elements for poultry production especially its moderate temperature range. Research efforts on effects of climate change on poultry production will contribute positively to knowledge of the problem climate change poses to poultry sector that bears the contribution to the economy of the developing countries in the supply of protein to a large number of populations and also the source of livelihood for the rural populace. The objectives of the study include determination of level of awareness of poultry farmers on climate change, perceived effects of climate change on feed - grain availability, perceived effects of climate change on egg and meat production pattern and distribution of poultry diseases due to effects of climate change.

\section{METHODOLOGY}

The study is conducted in Ondo State generally referred as "Sunshine State" is located in the South-western Nigeria. The state lies between longitude $4^{\circ} 30^{\prime}$ and $6^{\circ} 60^{\prime}$ East of Greenwich meridian and latitude $5^{\circ} 45^{\prime}$ and $8^{\circ} 15^{\prime}$ North of Equator. The State has a land mass of $14,793 \mathrm{sq} \mathrm{km}$ with a population of $3,441,024$ (NPC, 2006). The tropical climate of the state has two broadly classified seasons: rainy season that starts from April and ends in October, and dry season that last between Novembers to March. It has a temperature range of $21^{\circ} \mathrm{C}-29^{\circ} \mathrm{C}$ with a relatively high humidity. The annual rainfall varies form $2000 \mathrm{~mm}$ in the southern areas to $1,150 \mathrm{~mm}$ in the northern areas. The major occupation of the people in the state is agriculture which offers $75 \%$ of employment to the people of the state. The state is blessed with environmental factors that encourage people in the state to venture into animal rearing, such as poultry, piggery, dairy and fishing (Amos, 2006).

For this study, simple random sampling technique was used to a total of 83 poultry farms with at least 4 poultry from each of the 18 local Government Areas in the state. A well structured interview schedule was used as primary source of data collection from the sampled poultry farmers. Data analysis was done using descriptive statistics such as frequencies distribution, and percentages to determine the perception of the respondents on effects of climate change on poultry production in the study area. Chi -square was used to test the formulated hypothesis.

\section{RESULTS AND DISCUSSION}

Age is an important factor among the socio-economic characteristics of poultry farmers as it determines the effectiveness and competence of labour availability for production. As 
indicated in Table 1, 42.2\% of the respondents are in their active age of 31 - 40 years, hence they have the ability to supply the required labour needed in the production process. On the educational level of the respondents which directly influence the farmers' ability to adequately keep record and make observation on how climate change influences their poultry production pattern, the table shows that only $42.2 \%$ of the respondents have tertiary education while $38.5 \%$ did not have any formal education, this is to say farmers with good educational background are most likely to have better ability to keep records and make observation on effects of climate change on their farms than the illiterates. The Table also depicts that respondents with years of farming experience of between $11-20$ and $20-30$ years have a total of $79.5 \%$, hence, majority of them have good years of farming experience and this may influence their level of performance and observation on variation on climatic elements and its effects on poultry production. Close to half $(44.6 \%)$ of the respondents practised intensive system of poultry production in the study area, this may be explained by the fact that the system has much smaller impact on global warming than the free range production system (Sluis, 2007).

Table1. Socio-economic characteristics of respondents in the study area

\begin{tabular}{|r|r|}
\hline & \\
\hline &
\end{tabular}

Source: Field survey, 2012.

As resulted $93.3 \%$ of the respondents agreed that they are aware of climate change; this is to say that the majority of the poultry farmers in the study area have noticed variation in climatic elements and are likely to observe how it will affect the rate of survival and performance of their poultry production. On the observed climatic variation, the table depicts that $78.4 \%$ of the respondents all agreed that temperature fluctuate in the study area. In similar vein, $98.8 \%$ of the respondents observed increased sunshine intensity in the study area, while $86.7 \%$ of the respondents agreed that global warming has effect on poultry production in the study area. Temperature fluctuation and increased sunshine intensity has negative consequence on poultry production. High temperature and sunshine intensity many at times result to high mortality of the chickens, low egg production and low feed in take with low production (ICAR, 2010).

Based on the perceived effects of climate change on feed grain availability to poultry farmers. Intensive poultry industries rely heavily on cereals grains as such as maize as their principal feed type, climate chang will likely have the pottentials to affect the availabilty of the feed grain which will put pressure on the poultry industries. The result presented in table 3 revealed that $34.9 \%$ of the respondents disagree that high temperature and low rainfall have resulted to high feed availability; this is to say that these factors have negatively affected feed availability to poultry farmers and also their production. From table 2 , majority $(72.4 \%)$ 
of the respondents agreed that prices of feed grains are usually high during hot and dry seasons which may significantly influence the cost production as well as the number of the birds the farmer will be able raise in his farm, similarly, majority $(73.5 \%)$ of the respondents also agreed that climate change has effect on feed grain availability, this may be due to high temperature and low rainfall which are hash climatic conditions that may result to low harvest and hence scarcity of feed grain and this may also affect the cost of feed and purchasing power of the poultry farmers, and consequently quantity of egg and meat produced in the farm.

Table 2. Distribution of respondents on Perceived effects of climate change on feed-grain availability

\begin{tabular}{|c|c|c|c|c|}
\hline Perceived effects & $\begin{array}{c}\text { SA } \\
\text { Frq }(\%)\end{array}$ & $\begin{array}{c}\text { A } \\
\text { Frq }(\%)\end{array}$ & Frq $(\%)$ & $\begin{array}{c}\text { D } \\
\text { Frq }(\%)\end{array}$ \\
\hline $\begin{array}{l}\text { High temperature and low rainfall have resulted to high feed } \\
\text { availability }\end{array}$ & $\begin{array}{c}10 \\
(12.0) \\
\end{array}$ & $\begin{array}{c}21 \\
(25.3)\end{array}$ & $\begin{array}{c}23 \\
(27.7)\end{array}$ & $\begin{array}{c}29 \\
(34.9)\end{array}$ \\
\hline Prices of feed -grain are usually high during hot and dry seasons & $\begin{array}{c}33 \\
(39.8)\end{array}$ & $\begin{array}{c}32 \\
(38.6)\end{array}$ & $\begin{array}{c}14 \\
(16.9)\end{array}$ & $4(4.8)$ \\
\hline $\begin{array}{l}\text { High temperature and low rainfall conditions reduces quality of } \\
\text { grains }\end{array}$ & $5(6.0)$ & $\begin{array}{c}27 \\
(32.5)\end{array}$ & $\begin{array}{c}20 \\
(24.1)\end{array}$ & $\begin{array}{c}31 \\
(37.3)\end{array}$ \\
\hline Climate change has effect on feed grain availability & $\begin{array}{c}39 \\
(47.0)\end{array}$ & $\begin{array}{c}22 \\
(26.5)\end{array}$ & $\begin{array}{c}10 \\
(12.0)\end{array}$ & $\begin{array}{c}12 \\
(14.5)\end{array}$ \\
\hline
\end{tabular}

Source: Field survey, 2012.

The result in table 3 shows that majority (94\%) of the respondents agreed that climate change affects egg and meat production pattern in the study area, in the same vein $78.4 \%$ of the respondents agreed that high temperature makes birds feed less and drink more water; this is because temperature reduces the feed intake of poultry birds and more energy is needed to conserve the heat caused by high temperature, hence, a decreased in the rate of feed intake which results to decrease in egg and meat production (Elijah and Adedapo, 2006). The perception of respondents on the effect of high temperature and low rainfall on quality of egg, more than half $(67.5 \%)$ of the respondents agreed that these factors have a negative effect on quality of egg in the study area. The Table further revealed that majority $(86.8 \%)$ of the respondents agreed that high sunshine intensity affects poultry egg and meat production in the study area. High temperature and sunshine intensity many at times results to high mortality of the chickens, low egg production and low feed in take with low production (ICAR, 2010).

Table 3. Distribution of respondents on perceived effects of climate change on poultry egg and meat production pattern

\begin{tabular}{|c|c|c|c|c|}
\hline Perceived effects on production pattern & $\begin{array}{c}\mathrm{SA} \\
\text { Frq }(\%)\end{array}$ & $\begin{array}{c}\mathrm{A} \\
\mathrm{Frq}(\%)\end{array}$ & $\begin{array}{c}\text { SD } \\
\text { Frq(\%) }\end{array}$ & $\begin{array}{c}\mathrm{D} \\
\text { Frq }(\%)\end{array}$ \\
\hline Climate change affects egg and meat production & $\begin{array}{c}56 \\
(67.5)\end{array}$ & $\begin{array}{c}22 \\
(26.5)\end{array}$ & $5(6.0)$ & - \\
\hline High temperature makes birds feed less and drink more water & $\begin{array}{c}33 \\
(39.8)\end{array}$ & $\begin{array}{c}32 \\
(38.6)\end{array}$ & $7(8.4)$ & $\begin{array}{c}11 \\
(13.3)\end{array}$ \\
\hline $\begin{array}{l}\text { High temperature and low rainfall leads to production of low quality } \\
\text { egg }\end{array}$ & $\begin{array}{c}34 \\
(41.0)\end{array}$ & $\begin{array}{c}22 \\
(26.5)\end{array}$ & $\begin{array}{c}12 \\
(14.5)\end{array}$ & $\begin{array}{c}15 \\
(18.1)\end{array}$ \\
\hline High sunshine affects egg production & $\begin{array}{c}54 \\
(65.1)\end{array}$ & $\begin{array}{c}18 \\
(21.7)\end{array}$ & $\begin{array}{c}18 \\
(21.7)\end{array}$ & $\begin{array}{c}11 \\
(13.3)\end{array}$ \\
\hline
\end{tabular}

Source: Field survey, 2012.

From the results in table 4 , majority $(90.4 \%)$ of the respondents reported that climate change has effect on distribution of poultry diseases, close to three quarter $(78.3 \%)$ of the respondents claimed that there are more poultry diseases than in the past as result of effect of climate change. The results in table 4 further revealed that majority $(95.2 \%)$ of the respondents agreed that moist climatic conditions encouraged the distribution and development of diseases and $68.7 \%$ of the respondents also confirmed that climate change 
has led to the development of new poultry diseases in the study area. High rainfall and relative humidity provides a conducive environment for breeding of parasites that causes out break of diseases which invariably reduces egg and meat production (Elijah and Adedapo, 2006).

Table 4. Distribution of respondents on perceived effects of climate change on poultry disease distribution

\begin{tabular}{|c|c|c|}
\hline Effects of climate change on disease distribution & $\begin{array}{c}\text { Yes } \\
\text { Frequency } \\
(\%)\end{array}$ & $\begin{array}{c}\text { Frequency } \\
(\%)\end{array}$ \\
\hline Does climate change have effect on the distribution of poultry diseases? & $75(90.4)$ & $8(9.6)$ \\
\hline Are there more poultry diseases now than in the past due climate change? & $65(78.3)$ & $18(21.7)$ \\
\hline Moist climatic conditions encourage the distribution and development of & $79(95.2)$ & $4(48.20)$ \\
\hline Has climate change led to the development of new poultry diseases? & $57968.7)$ & $26(31.3)$ \\
\hline
\end{tabular}

Source: Field survey, 2012.

\section{Testing of hypotheses.}

$\mathrm{Ho}_{1}$ : There is no significant relationship between selected socio-economic characteristics of poultry farmers and their perceived effects on climate change.

The result shows of chi-square analysis in table 5 shows that there is a significant relationship between respondents' socio-economic characteristics and perception of poultry farmers on effects of climate change on poultry production since $p>0.05(r=0.454$, $p=0.001$ ). The $r^{2}$ value of 0.454 shows a good relationship between socio-economic characteristics and perception of poultry farmers on effects of climate chnage on poultry production. This implies that socio-economic characteristics influence the perception of the poultry farmers on the effect of climate change on poultry production in the study area. This may be explained on the basis of the fact that majority of the men and women, the young and old, the literate and illiterate as well as people that practice different system of poultry farming are aware of climate change in the study area.

Table 5. Relationship between socio-economic characteristics of respondents and perceived effect of climate change on poultry production

\begin{tabular}{|c|c|c|c|c|c|c|}
\hline Variables & $\mathrm{N}$ & $X$ & SD & $\mathrm{R}$ & Significant & Decision \\
\hline $\begin{array}{l}\text { Socio-economic } \\
\text { characteristics }\end{array}$ & 83 & 1.2 & 0.53 & $0.454^{\star *}$ & 0.001 & $\mathrm{H}_{\mathrm{o}}$ \\
\hline Perceeved effects & 83 & 1.24 & 0.49 & $0.454^{\star \star}$ & 0.001 & Rejected \\
\hline
\end{tabular}

Source: Field survey, 2012.

$\mathrm{Ho}_{2}$ : There is no significant relationship between selected socio-economic characteristics of poultry farmers and their level of awareness of climate change.

The chi-square result in table 6 also shows that there is a significant relationship between socio-economic characteristics of respondents and their level of awareness of climate change since the $p>0.05(r=0.652, p=0.001)$.. This implies that socio-economic characteristics of the poultry farmers have influence on their level of awareness of the effect of climate change on poultry production.

Table 6. Relationship between some selected socio-economic characteristics of respondents and their level awareness of climate change

\begin{tabular}{|c|c|c|c|c|c|c|}
\hline Variable & $\mathrm{N}$ & $\mathrm{X}$ & $\mathrm{SD}$ & $\mathrm{R}$ & Significant & Decision \\
\hline Socio-economic characteristics & 83 & 1.21 & 0.32 & $0.652^{\star *}$ & 0.001 & $\mathrm{H}$ \\
\hline Level of awareness of climate change & 83 & 1.21 & 0.44 & $0.652^{\star \star}$ & 0.001 & Rejected \\
\hline
\end{tabular}

Source: Field survey, 2012. 


\section{CONCLUSION}

The study reveled that majority of the respondents are aware of the climate change and hence, most likely to make observation on how it affect poultry production pattern, effects of climate change which results in temperature fluctuation, increased in sunshine intensity and global warming has a negative effects on poultry production which many at times results to high mortality rate of the chickens, low egg and meat production and prices of feed grains are usually high in hot and dry seasons as result of effects of climate change which may affect cost of production and number of birds to raise for egg and meat production in the farm.

From the findings of the study, egg and meat production pattern are affected by climate change because periods of high temperature and sunshine intensity makes the birds to drink more water and reduce feed intake which many at times results to high mortality of the chickens, low egg production and low feed conversion ability of the birds to meat, hence, low meat production (ICAR, 2010). The sudy further revealed that climatic changes influence the emergence of new poultry diseases and increased its didtribution. There is dire need to intensify awareness campaign to poultry farmers on how to reduce the effects of climate change on poultry production. Extension agents and other development agencies need to educate the poultry farmers more about the effects posed by climate change on poultry production.

\section{REFERENCES}

[1] Amos, T.T (2006). Analysis of Backyard Poultry Production in Ondo State, Nigeria. International Journal of Poultry Science 5(3): 247-250.

[2] Avila, M., (1985). Intra and inter-household decisionmaking in the Mangwende and Chivi Communal Areas: Preliminary results, Farming System Research Unit, Harare.

[3] Demeke, S (2004). Egg Production and Performance of local white leghorn hens under intensive and rural household conditions in Ethiopia. LRRD 16: 2.

[4] Elijah, O.A. and A. Adedapo (2006). The effect of climate on poultry productivity in Ilorin Kwara State, Nigeria. International journal of poultry Science., 5(11): 1061-1068.

[5] Guis,H., C. Caminade., C. calvete., A.P. Morse., A. Tran and M. Baylis (2011). Modelling The effects of past and future climate on the risk of bluetone emergence in Europe. Journal of Rural Sociology Interface (In press). 10. 1098/rsif.2011.0255.

[6] India Council of Agricultural Research (ICAR). 2010-11 annual Report Pp 13.

[7] Olanrewaju, H.A., J.L. Purswell., S.D. Collier and S.L. Branton (2010). Effect of Ambient Temperature and Light Intensity on Growth Performance and Carcass Characteristics of Heavy Broiler Chickens at 56 Days of Age. International Journal of Poultry Science 9 (8): 720-725.

[8] Ponapa, C.G. (1982). Eggs in child's Nutrition. Poult. Adv., 51-53.

[9] Sluis, W. V. (2007). Intensive poultry Production. World poultry Megazine 23 (12). Retrieved from www.worldpoultry.net on $15^{\text {th }} / 01 / 2013$. 